\title{
Características Microbiológicas de Mucor sp.
}

\author{
Sebastian Iglesias-Osores ${ }^{1 a}$, Hernán Rodriguez-Perla2 ${ }^{2 b}$
}

Las zigomicosis son micosis causadas por hongos oportunistas pertenecientes al phyllum Zygomycota, clase Zygomycetos, orden Mucorales, familia Mucoraceae (1). Los géneros de mayor relevancia son Rhizopus, Mucor y Lichteimia (Absidia), siendo estos causantes del 70 al $80 \%$ de casos reportados ${ }^{(2)}$. Las infecciones fúngicas son importantes causas de movilidad y mortalidad en pacientes inmunocomprometidos, esto puede observarse particularmente en neonatos y pacientes con diabetes mellitus, heridas causadas por cirugía, traumatismos y quemaduras ${ }^{(3)}$.

Mucor spp. son de rápido crecimiento en el medio de cultivo, produciendo esporangios en esporangióforos globosos, solitarios o ramificados (figura 1 y 2). Los esporangios contienen toda la columela y esporas, pudiendo ser delicuescentes (en disolución). Los esporangios tienen una pared delgada que, cuando madura, se rompe irregularmente para liberar esporangiosporas redondas o elipsoidales (4 a $8 \mu \mathrm{m}$ de diámetro). Con las esporas dispersas, la columela que llevaba los esporangios es visible, dejando a veces un collar en la base del esporangio (figura 3). Los rizoides y los estolones están ausentes, lo que lo diferencia del género Rhizopus, así como la ausencia de apófisis debajo del esporangio lo diferencia de Absidia. Además, Mucor produce clamidoconideas y es inhibido por la ciclohexmida ${ }^{(1)}$.

El diagnóstico está basado en técnicas microbiológicas y anatomopatológicas. Las pruebas serológicas de diagnóstico para la detección de Zigomicosis no son clínicamente útiles, debido a que los zigomicetos comparten varios determinantes antigénicos entre sí. El diagnóstico molecular aun esta en proceso de investigación, no obstante estudios de complementariedad de ADN y la PCR u otras técnicas moleculares son usados para su clasificación y taxonomía ${ }^{(2,3)}$.

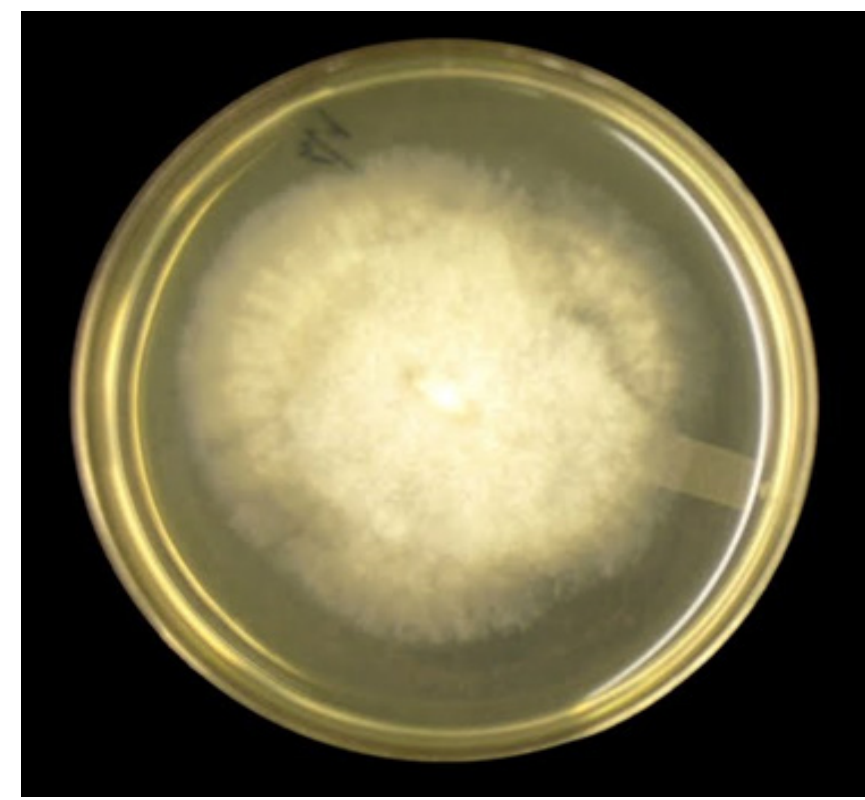

Figura 1: Mucor sp. en placa de agar Sabouraud con 48 horas de crecimiento a $30^{\circ} \mathrm{C}$.

\footnotetext{
1. Hospital Regional Lambayeque. Chiclayo, Perú.

2. Facultad de Medicina Humana, Universidad de San Martin de Porres. Chiclayo, Perú.

a Biologo

${ }^{\mathrm{b}}$ Médico cirujano
} 


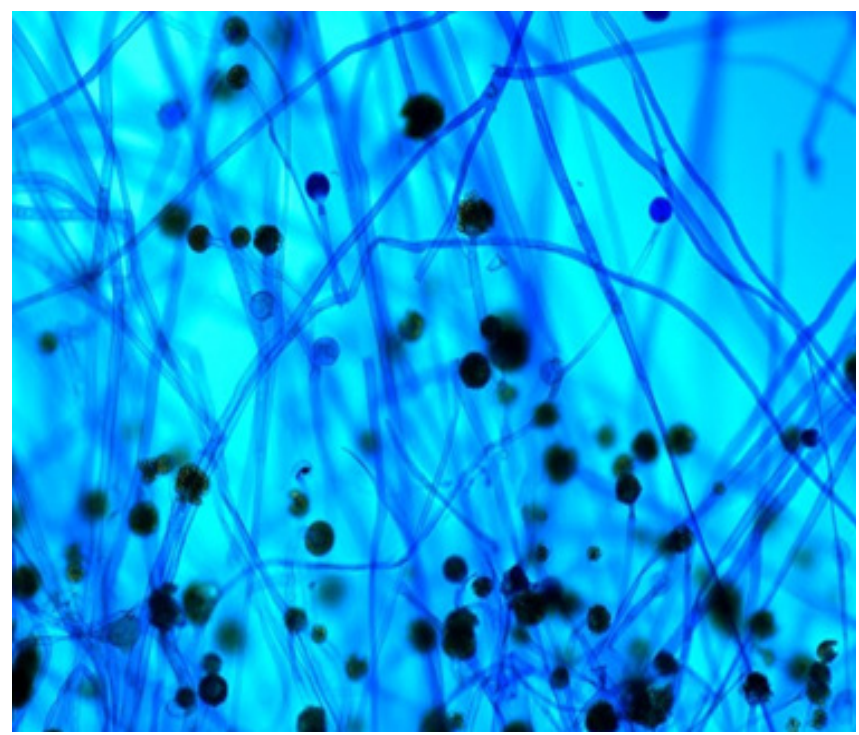

Figura 2: Hifas escasamente septadas, esporangióforos con esporangios (tinción azul de Lactofenol o azul algodón X100).

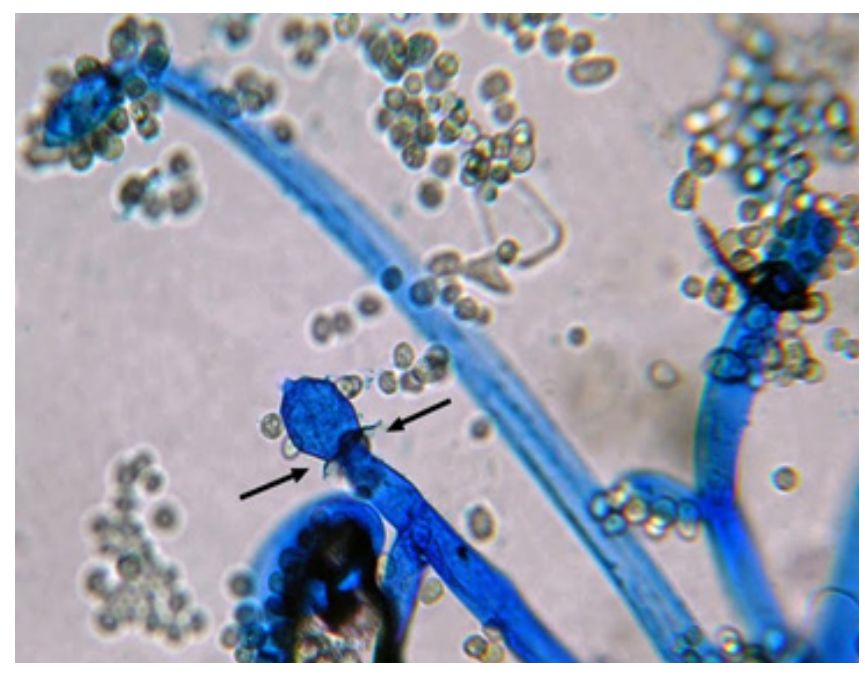

Figura 3: esporas dispersas, la columela se revela con el collarín que queda debajo (flechas) (Aumento de 40X, tinción algodón de azul).

Agradecimiento: agradecemos a Yuri Amatnieks, HBSc, MLT por haber cedidos las fotos la su publicación en este artículo.

\section{REFERENCIAS BIBLIOGRÁFICAS}

1. Ribes JA, Vanover-Sams CL, Baker DJ. Zygomycetes in human disease. Clin Microbiol Rev. 2000; 13(2): 236-301.

2. West BC, Oberle AD, Kwon-Chung KJ. Mucormycosis caused by Rhizopus microsporus var. microsporus: cellulitis in the leg of a diabetic patient cured by amputation. J Clin Microbiol. 1995; 33(12):3341-4.

3. Katragkou A, Walsh TJ, Roilides E. Why is mucormycosis more difficult to cure than more common mycoses? Clin Microbiol Infect. 2014; 20:74-81. 